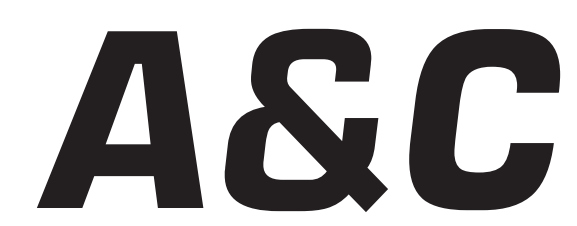

Revista de Direito Administrativo \& Constitucional

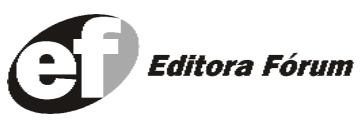

A\&C R. de Dir. Administrativo e Constitucional, Belo Horizonte, ano 5, n. 21, p. 1-252, jul./set. 2005 


\section{A\&C REVISTA DE DIREITO ADMINISTRATIVO E CONSTITUCIONAL}

\section{IPDA}

Instituto Paranaense

de Direito Administrativo

Direção Geral

Romeu Felipe Bacellar Filho

Direção Editorial

Paulo Roberto Ferreira Motta

Direção Executiva

Emerson Gabardo

Conselho de Redação

Edgar Chiuratto Guimarães

Adriana da Costa Ricardo Schier

Célio Heitor Guimarães

Conselho Editorial

Adilson Abreu Dallari

Alice Gonzáles Borges

Carlos Ari Sundfeld

Carlos Ayres Britto

Carlos Delpiazzo

Cármen Lúcia Antunes Rocha

Celso Antônio Bandeira de Mello

Clèmerson Merlin Clève

Clóvis Beznos

Enrique Silva Cimma

Eros Roberto Grau

Fabrício Motta

Guilhermo Andrés Muñoz (in memoriam)

Jaime Rodríguez-Arana Muñoz

Jorge Luís Salomoni
José Carlos Abraão
José Eduardo Martins Cardoso

José Luís Said

José Mario Serrate Paz

Juan Pablo Cajarville Peruffo

Juarez Freitas

Julio Rodolfo Comadira

Luís Enrique Chase Plate

Lúcia Valle Figueiredo

Manoel de Oliveira Franco Sobrinho

(in memoriam)

Marçal Justen Filho

Marcelo Figueiredo

Márcio Cammarosano

Maria Cristina Cesar de Oliveira
Nelson Figueiredo

Odilon Borges Junior

Pascual Caiella

Paulo Eduardo Garrido Modesto

Paulo Henrique Blasi

Paulo Neves de Carvalho (in memoriam)

Paulo Ricardo Schier

Pedro Paulo de Almeida Dutra

Regina Maria Macedo Nery Ferrari

Rogério Gesta Leal

Rolando Pantoja Bauzá

Sérgio Ferraz

Valmir Pontes Filho

Yara Stropa

Weida Zancaner

\footnotetext{
A246 A\&C Revista de Direito Administrativo e Constitucional. ano 3, n. 11, jan./mar. 2003. Belo Horizonte: Fórum, 2003.

Trimestral

ano 1, n.1, 1999 até ano 2, n.10, 2002 publicada pela Editora Juruá em Curitiba

ISSN: 1516-3210

1. Direito Administrativo. 2. Direito Constitucional. I. Fórum.
}

CDD: 342 CDU: 33.342

(c) Editora Fórum Ltda. 2005

Todos os direitos reservados. É proibida a reprodução total ou parcial, de qualquer forma ou por qualquer meio eletrônico ou mecânico, inclusive através de processos xerográficos, de fotocópias ou de gravação, sem permissão por escrito do possuidor dos direitos de cópias (Lei $n^{\circ}$ 9.610, de 19.02.1998).

Editora Fórum Ltda

Av. Afonso Pena, 2770 - 15\%16ªndar - Funcionários

CEP 30130-007 - Belo Horizonte/MG - Brasil

Tel.: 08007043737

Internet: www.editoraforum.com.br

e-mail: editoraforum@editoraforum.com.br
Editor responsável: Luís Cláudio Rodrigues Ferreira Projeto gráfico e diagramação: Luis Alberto Pimenta Revisora: Olga M. A. Sousa

Pesquisa jurídica: Fátima Ribeiro - OAB/MG 74868

Bibliotecária: Nilcéia Lage de Medeiros

CRB 1545/MG 6a região

Os conceitos e opiniões expressas nos trabalhos assinados são de responsabilidade exclusiva de seus autores.

Impressa no Brasil / Printed in Brazil

Distribuída em todo Território Nacional 


\title{
Impasses Sistêmicos da Versão Brasileira de Precedentes Vinculantes
}

\begin{abstract}
Vanice Lírio do Valle
Doutoranda em Direito pela Universidade Gama Filho. Mestre em Direito pela Universidade Estácio de Sá. Diretora do Departamento de Ciências Jurídicas da Universidade Gama Filho. Procuradora do Município do Rio de Janeiro ${ }^{1}$

Sumário: 1 Introdução - 2 Sistema de precedentes vinculantes: virtudes e dificuldades em seu desenho em tese - 3 Primeira crítica à versão brasileira de vinculatividade de decisões judiciais: súmula como instrumento de "pacificação", e não de construção do Direito - 4 Segunda crítica à versão brasileira de vinculatividade de decisões judiciais: a resposta constitucional à contrariedade ou má aplicação da súmula - $\mathbf{5}$ Terceira crítica à versão brasileira de vinculatividade de decisões judiciais: a inconsistência sistêmica - Bibliografia
\end{abstract}

\section{Introdução}

O debate acerca da utilidade da adoção de um sistema de precedentes vinculantes é tema recorrente na comunidade jurídica brasileira, ecoando iniciativas ou experiências alienígenas, cuja importação se propugna, no mais das vezes sem o prévio aprofundamento de investigação no que toca às características peculiares dos modelos apontados como possíveis paradigmas. Aliás, essa ausência de investigação — seja quanto aos méritos da proposta, seja no que toca à verdadeira dimensão e natureza do problema que ela pretenderia superar — revela-se a tônica da nossa tendência à supervalorização de modelos estrangeiros, já advertia Barbosa Moreira (2000, p. 32-33), em estudo hoje clássico acerca das iniciativas de reforma do Código de Processo Civil.

A influência, não vinculante, mas persuasiva, de decisões pretéritas, não é, em absoluto, traço estranho ao sistema brasileiro. Ao contrário já adverte Greco (2004, p. 44) - cuida-se de "...herança do velho Direito português, desde as Ordenações do Reino, através dos assentos da Casa de Suplicação de Lisboa e dos Supremos Tribunais de Justiça de Portugal e do Brasil, este último no império". Mais ainda, o cuidado com a harmonização das manifestações das Cortes se revela em diversos institutos processuais brasileiros, sendo possível apontar - adotando como marco temporal, a própria edição do CPC - desde figuras como o incidente de uniformização de jurisprudência (arts. 476 a 479 do CPC), cuja previsão já se continha nos E-mail <liriodovalle@uol.com.br>. 
seus termos originais datados de 1973; passando ainda por meios de impugnação de status constitucional trazidos originariamente pela Carta de Outubro (art. 105, III, “c”, conferindo competência ao STJ para julgar em recurso especial, as causas que envolvam divergência na interpretação da lei federal); até alcançar previsões mais recentes, impulsionadas pela onda de reformas da legislação processual civil, como, dentre outras, a contida no art. 557 , caput e $\S 1^{\circ}$ do CPC, que confere ao relator de poderes decisórios, de negativa de seguimento, ou ainda de seu provimento, tudo por intermédio de decisão monocrática, desde que identificado contraste com a “...jurisprudência dominante...”."

Inobstante esse crescendo de importância da aferição de harmonia entre a decisão sob escrutínio e a crônica de decisões no tema, a vinculatividade — no sentido de imposição de obrigatória observância aos demais órgãos do Poder Judiciário e mesmo aos demais Poderes — só se veiculou no direito brasileiro, com a edição da Emenda Constitucional no 3/93, que conferindo nova redação aos termos do $\S 2^{\circ}$ do art. $103,{ }^{3}$ consagrou tal traço às decisões definitivas de mérito proferidas pelo Supremo Tribunal Federal nas ações declaratórias de constitucionalidade.

Observe-se que mesmo essa primeira experiência com a consagração de vinculatividade de decisão judicial não se deu sem despertar intensa polêmica, tendo o STF debatido longamente no curso da Ação Declaratória de Constitucionalidade $\mathrm{n}^{\circ} 1 / \mathrm{QO}$, qual a adequada compreensão a se conferir à expressão “...efeito vinculante...” trazida pelo constituinte reformador, e mais ainda, qual o significado de sua conjugação com a referência, no mesmo texto, a “...eficácia contra todos...”. ${ }^{4}$

\footnotetext{
2 Em verdade, a sistemática instituída pela Lei $n^{\circ}$ 9.756, de 17.12.1998 autoriza a negativa de seguimento "... a recurso manifestamente inadmissível, improcedente, prejudicado ou em confronto com súmula ou com jurisprudência dominante do respectivo tribunal, do Supremo Tribunal Federal, ou de Tribunal Superior...", e ainda o provimento de recurso interposto para impugnar decisão "... em manifesto confronto com súmula ou com jurisprudência dominante do Supremo Tribunal Federal, ou de Tribunal Superior...". Observe-se que a figura da "jurisprudência dominante" ganha, com essa previsão legal, relevância, seja qual for o nível hierárquico em que ela se tenha formado, vez que o contraste entre ela e a pretensão articulada no recurso já permitirá, quando menos, a inadmissão monocrática do meio de impugnação.

3 Esse mesmo dispositivo constitucional recebeu nova roupagem, com a aprovação da Emenda n 45/04, que passou a incluir no campo da incidência do efeito vinculante, as decisões definitivas de mérito proferidas em ações diretas de inconstitucionalidade. Curiosa a providência do constituinte reformador, na medida em que, resultando da decisão definitiva de mérito proferida em ação declaratória de inconstitucionalidade, a exclusão do mundo jurídico da lei reconhecida como viciada de origem, não há como se reconhecer a essa mesma decisão efeito que não possa ser vinculante...

$4 \mathrm{Na}$ análise da ADC n 1/QO, sustentou seu Relator, o Min. Moreira Alves a compatibilidade com o Texto de Base, do efeito vinculante da decisão de mérito proferida em ação declaratória de constitucionalidade, instituído pela Emenda Constitucional n 3/93. Em verdade, sustentava-se ali que, tendo em conta o valor pretendido tutelar com a instituição da ação declaratória de constitucionalidade - a saber, segurança jurídica, comprometida com freqüente multiplicidade de compreensões em relação a um mesmo ato normativo
} 
Sucumbindo porém à ênfase com que a idéia da vinculatividade se apresentava - e desconhecendo o truísmo expresso na assertiva de que ênfase não é argumento - a recente edição da Emenda Constitucional $\mathrm{n}^{\circ}$ $45 / 04$ vem a introduzir a figura do precedente vinculante, formalizado, não pela outorga desse signo a uma determinada decisão judicial ou a um conjunto delas, mas veiculado através de enunciado da Súmula do STF, nos termos do sistema instituído pela redação que confere ao art. 103-A da Carta de Outubro.

A figura da súmula vinculante - a par de toda paixão que desperta no que toca aos eventuais limites que impõe ao pleno exercício da jurisdição no que toca às instâncias do Judiciário a ela subordinadas ${ }^{5}-$ apresenta, nos termos em que foi trazida à luz no ordenamento jurídico pátrio, uma série de paradoxos quando se tem em conta uma visão sistêmica de nosso Direito. Cumpre, portanto, um esforço de interpretação conforme a Constituição, de molde a evitar que o instrumento - mal ou bem já introduzido no ordenamento constitucional — sofra ainda maiores distorções na sua aplicação.

\section{Sistema de precedentes vinculantes: virtudes e dificuldades em seu desenho em tese}

Proposta a análise — ainda que perfunctória — da "versão brasileira" do sistema de precedentes que se introduz com a Emenda Constitucional $\mathrm{n}^{\mathrm{o}} 45 / 04$, indispensável um breve percurso aos méritos (e deméritos) que a experiência anterior de outros países tem apontado. Afinal, é à luz desses prováveis benefícios que se poderá aferir a (in)adequação da trajetória adotada pelo Direito brasileiro; mais ainda, o alcance desses mesmos objetivos poderá orientar a construção do significado possível ao sistema instituído pela Emenda Constitucional n ${ }^{\circ}$ 45/04.

Embora a consideração das decisões havidas anteriormente, em algum grau, seja prática comum aos sistemas judiciários de todo o mundo — em verdade, essa se constitui prática típica, pode-se dizer, até mesmo da racionalidade humana, que aprende e se orienta a partir de suas

\footnotetext{
— a vinculatividade do decidido se impunha. Mais ainda, o caráter evidentemente ambivalente da açã declaratória de constitucionalidade (que improcedente no mérito, tem por resultado, a afirmação da inconstitucionalidade da norma sob exame) haveria de exigir a vinculatidade da decisão, que declarando o vício de raiz e expungindo a norma do mundo jurídico, não pode ter eficácia limitada ou parcial.

5 Boa parte do debate que antecedeu à aprovação dos termos da Emenda Constitucional $n^{\circ}$ 45/04 imputava à súmula vinculante uma indesejável subordinação das decisões - em especial, da justiça de primeiro grau - aos critérios, não necessariamente mais acertados e isentos, dos órgãos de cúpula do próprio Judiciário.
} 
experiências anteriores - a máxima intensificação dessa consideração, que se traduz no precedente vinculante (no sentido de subordinante, quando menos, de algumas instâncias do próprio Poder Judiciário), é característica que não se identifica presente em muitos sistemas nacionais. Assim é que na Alemanha, embora os precedentes tenham inegável importância na construção da solução, o sistema não assinala a eles caráter vinculante (MOREIRA LIMA, 2001, p. 27). Na França, por sua vez, a simples indicação de precedentes como fundamento de decisão é tida por insuficiente, à vista do primado da lei como instrumento da volonté générale (MOREIRA LIMA, 2001, p. 33). ${ }^{6}$ Por derradeiro, na Itália, embora se consigne uma referência histórica ao poder vinculante de precedentes, lançada na Regie Costituzione do Estado de Piemonte (art. $5^{\circ}$, Título 22, Livro 3); em 1848, com o Statuto Albertino tal possibilidade se viu superada, e até hoje - embora o tema tenha retornado à consideração dos estudiosos, como destaca TARUFFO (1994a, p.19-36), nem por isso se teve a restauração da vinculatividade.

Mas qual a extensão do conceito com que se lida, quando se alude - para os fins propostos ao presente trabalho - a adesão obrigatória à decisão prévia?

Precedente vinculante - tendo-se por referência, a sempre citada experiência americana, (COLE, 1998, p. 71) “... é a regra de direito usada por uma Corte de segunda instância no sistema judiciário em que o caso está para ser decidido, aplicada aos fatos relevantes que criaram a questão colocada para a Corte para decisão...". Cuida-se, portanto, de uma unidade sistêmica, que compreende, de um lado, os fatos submetidos à apreciação; e, de outro, os parâmetros normativos aplicáveis em tese; elementos esses que conjugados, permitem, através da interpretação jurídica, a formulação em concreto, de um juízo decisório. ${ }^{7} \mathrm{Na}$ mesma linha de conteúdo se tem o conceito oferecido à idéia de precedentes obrigatórios no sistema inglês, fortemente influenciada pela máxima judge made law, que se apresenta como um importante traço garantidor da flexibilidade e atualidade

${ }^{6}$ Embora a idéia tradicional do primado da lei como expressão da volonté générale ceda já hoje espaço para a admissibilidade de controle de sua compatibilidade com a Constituição, como admitido pela seminal referência da "... Decision du 23 août 1985 du Conseil constitutionnel: 'La loi votée... n'exprime la volonté génerále que dans lê respect de la Constitution'..." (BLACHÈR, 2001, p. 12); fato é que disso não se pode extrair a conclusão de seu esvaziamento enquanto única fonte formal do Direito. É nessa perspectiva que a presença da fundamentação legal, stricto sensu, ainda se põe como indispensável à observância ao dever de motivas das decisões judiciais, razão pela qual a invocação dos precedentes se põe ainda de forma mais tênue (MOREIRA LIMA, 2001, p. 33).

7 Da indispensável convergência de moldura de fato e parâmetros normativos abstratamente considerados, na busca da construção do critério jurídico de decisão, dá notícia Castanheira Neves (2003, p. 28) "... a referência desse critério [jurídico de decisão] ao mérito deste problema ou a compreensão-assimilação intencionalmente normativa daquele critério justamente como critério normativo da concreta solução do problema jurídico, é o que essencialmente exige e constitui a interpretação jurídica...". 
do sistema jurídico (STRECK, 2002, p. 233-235).

Traçada o conceito e identificados os elementos, desponta a assertiva de MacCormick (1997, p. 1-2) no sentido de que um corpo de precedentes disponível à consideração quando da prolação de uma decisão judicial representa, quando menos, uma acumulação de sabedoria originária do passado, servindo a uma inclinação que é própria do uso da razão prática, a saber, o uso como referência, do acervo de informações constituído a partir de escolhas pretéritas.

A par desse elemento - primário — de facilitação da decisão, o sistema de precedentes vinculantes permite ainda um alto nível de previsibilidade da solução do problema submetido à apreciação do Judiciário, e por via de conseqüência, uma “...estabilidade para os propósitos do processo decisório...” (COLE, 1998, p. 83).

Também no plano da legitimidade da decisão lançada como critério jurídico de solução, o sistema de precedentes vinculantes se apresenta como uma alternativa útil, vez que ele a um só tempo, reforça o elemento de impessoalidade da solução oferecida em concreto ao caso sob exame — a decisão é do juiz que a prolata, mas não só dele, não subjetivamente dele - e ainda agrega à sua cadeia de autoria, um conjunto de outros agentes do Poder Judiciário que oficiaram em outras demandas, ${ }^{8}$ distintas, mas de características assemelhadas a ponto de permitir a invocação da vinculatividade.

Ainda nesse mesmo plano de legitimidade — adotada a compreensão de que seja ele reverenciado pela motivação das decisões judiciais — não resta dúvida que, sob o prisma da argumentação racional, de grande valia será também o emprego do sistema da stare decisis. E isso se afirma por duas razões: primeiro, a própria afirmação da existência e aplicabilidade à hipótese concreta de precedente vinculante atrai para si todo o esforço pretérito, dos órgãos jurisdicionais que anteriormente examinaram o tema, de desenvolvimento e construção do critério jurídico de solução extensível pela força impositiva do precedente; segundo, a própria aferição dessa mesma existência e aplicabilidade do precedente determinará um detalhamento de análise da situação de fato submetida à apreciação judicial, e dos parâmetros jurídicos aplicáveis a essa mesma hipótese,

\footnotetext{
8 Interessante a observação de MacCormick (1997, p. 2) no sentido de que esse integrar uma corrente de decisões que consolidam e conformam a compreensão de um determinado tema jurídico aplicado ao caso concreto gera também nos magistrados um sentimento de agregação a essa quase decisão coletiva, despertando portanto um especial comprometimento com esse processo de construção dos precedentes que guiarão as decisões futuras.
} 
que só contribui para o aperfeiçoamento da decisão, e para o seu nível de satisfação em relação àqueles a quem ela se dirige. ${ }^{9}$

É curioso esse efeito do sistema de stare decisis: ao revés do que se vê no imaginário menos informado, a decisão que cogita de um precedente vinculante (aplicando-o ou afastando sua incidência pelo distinguishing) percorre um iter complexo, que valorizando o ônus argumentativo do órgão que decide, contribui, por uma operacionalização permanente (que começou no precedente original, prossegue na análise do caso concreto e prossegue no enfrentamento futuro das hipóteses que terão a essa situação em análise também por precedente) de um ajuste fiscalizatório abstrato e em concreto do discurso constitucional positivado, para a preservação da opção, também constitucional, do Estado Democrático de Direito. ${ }^{10}$

Mais ainda, a idéia da vinculação aos precedentes - e nesse particular, a afirmação se prende mais fortemente a sua ocorrência normalmente em países de sistema de common law — permite uma construção paulatina do conteúdo e significado dos critérios jurídicos aplicáveis ao enfrentamento dos casos concretos postos pela realidade da vida. Assim, consigna MacCormick (1997, p. 5) “...the elaboration of law throght precedente is usually slower, more evolutionary business, in wich by na incremental process small adjustments are made case by case, usually never more then necessary for solving the problem in each case, always correctable in the light of experience throught overrruling of discovered mistakes by highest-level-appeal courts..." - concepção que Dworkin (1999, p. 275), por sua vez, associava à imagem do romance em cadeia, segundo a qual, cada juiz, a um só tempo, crítico (literário, na imagem do autor) e autor, interpreta e agrega sua contribuição pessoal à atuação do que lhe antecedeu na aplicação do mesmo parâmetro normativo. É de se considerar ainda que o precedente obrigatório se estabelece dentro de uma perspectiva hierárquica — órgão jurisdicional superior, no mesmo âmbito de competência, formaliza a decisão, cuja força vinculante se põe aos níveis inferiores daquela mesma estrutura judiciária.

Completam as linhas-mestras do sistema, as figuras do distinguishing — através da qual se evidenciam os elementos distintivos entre o caso

\footnotetext{
9 É extreme de dúvidas a circunstância de que a decisão decorrente de detalhado percurso de análise tende a gerar - mesmo em relação àquele vencido - maior nível de satisfação, ou quando menos, de conformismo, em relação a seu resultado, que aquele sumária e pouco clara no que toca a seus fundamentos.

10 Sobre o tema da relação entre estrutura procedimental processualizada, fundamentação de decisões e Estado Democrático, veja-se Leal (2002, p. 129-131).
} 
sob exame e os precedentes apontados — e do overruling — que viabilizam a reconsideração do precedente antes estabelecido, pelo mesmo órgão jurisdicional ou por outro, de superior posição hierárquica, cabível nas hipóteses em que o paradigma jurisdicional estabelecido não mais se tenha por adequado. ${ }^{11}$

No campo dos argumentos de contradita, impõe-se apontar o chamado caráter ficcional (TARUFFO, 1994a, p. 4) ou ilusionista (ROSS, 2003 , p. 115) do modelo de precedentes vinculantes, na medida em que as aberturas que contém (sejam as originárias, como o distinguishing e o overrruling, sejam as recentemente incorporadas a seu desenho teórico), destinadas a preservar a oxigenação do sistema, não só erodem seus próprios fundamentos, ${ }^{12}$ como também permitem uma verdadeira ocultação da real atividade criadora desenvolvida, eventualmente, pelo Judiciário. Mais ainda, a excessiva flexibilidade — ou ausência de critérios minimamente objetivos - que permitam a identificação da porção da decisão que se revista de efeito vinculante constitui, já assinalava Taruffo (1994b, p. 44), uma dificuldade prática substantiva à adequada aplicação do modelo. ${ }^{13}$

Por derradeiro, têm-se ainda apontado que a suposta virtude do stare decisis consistente no permitir uma oxigenação do sistema jurídico como um todo, ao contrário, pode gerar - até mesmo por inércia das estruturas formais de poder, e pelo conservadorismo típico da função jurisdicional — uma cristalização da compreensão dos temas já objeto de precedente formalizado.

Fato é que a idéia de stare decisis não mais encontra tradução, mesmo nos países berço desse sistema, no seu modelo originário. Assim é que, no sistema inglês, a introdução de law reports e leis originárias do Parlamento já interfere naquela concepção de que a lei inglesa consista (exclusivamente) do trabalho dos juízes (STRECK, 2002, p. 233). Mesmo em terras norteamericanas, não se encontra mais o mesmo vigor em relação aos limites ou à defesa do modelo de adesão incondicional aos precedentes. Esse imperativo de temperamento do sistema, aliás, já na década de 30 era precedentes vinculantes, sempre na linha de "ventilação" das decisões, de forma a que elas atendam ao ideal de realização da justiça. Assim é que a possibilidade de sua não aplicação, pelo próprio juízo de hierarquia inferior, à conta da mudança das circunstâncias sociais, históricas ou econômicas: o reconhecimento da ancianidade do precedente; todas são novas brechas no caráter vinculante dos precedentes, admitidas pelas Cortes americanas.

12 Vasto elenco de possibilidades de afastamento do precedente vinculante, em verdade, compromete o traço de estabilidade e previsibilidade que do sistema deveria decorrer.

13 Com efeito, embora a enunciação teórica de que o precedente se tenha por limitado à ratio decidenci, não se reconhecendo força vinculante às obiter dicta, a prática do sistema — aponta MacCormocik (1997 p. 383-387) - a admite distintos níveis ou focos de análise do que se possa qualificar como ratio ou dicta, tendo em conta não só a estrutura do precedente, como também sua relação com a hipótese em concreto que envolva à sua aplicação. 
preconizado peloJustice Cardozo, nos seguintes termos (CARDOZO, 2004, p. 111): “...estou disposto a admitir que a regra da adesão ao precedente, embora não deva ser abolida, deve até certo ponto ser relaxada. Quando uma norma, após ter sido devidamente testada pela experiência, revela-se incompatível com o senso de justiça ou com o bem-estar social, penso que deveria haver menos hesitação em admitir-se isso francamente e aboli-la por completo".

Como se vê, a opção pelo modelo proposto no sistema de precedentes vinculantes, também vem sendo, em si, objeto de reflexão no que toca à sua eficácia e adequação aos novos tempos, à celeridade das mudanças e aos imperativos de um Judiciário menos comprometido com a forma, e mais com o resultado primário de concretização de justiça. Esse é o contexto com o qual cumpre avaliar a "versão brasileira" da idéia de adesão ao precedente, instituído pela Emenda Constitucional no 45/04.

\section{Primeira crítica à versão brasileira de vinculatividade de decisões judiciais: súmula como instrumento de "pacificação", e não de construção do Direito}

Primeiro ponto de destaque na sistemática instituída pela Emenda Constitucional $\mathrm{n}^{\mathrm{O}} 45 / 04$ diz respeito aos pressupostos traçados pelo art. 103-A, $\S 1^{\circ}$ da Constituição Federal, a saber: “...controvérsia atual entre órgãos judiciários ou entre esses e a administração pública...”, qualificada pelo risco de geração de “...grave insegurança jurídica..." ${ }^{14}$ e “...relevante multiplicação de processos...”. Vê-se, a partir dessa moldura de cabimento, que a vinculatividade tupiniquim tem como móvel, não a construção gradual da melhor compreensão do Direito, mas sim a pacificação de um conflito que ameace a um só tempo, o Estado Democrático de Direito e à eficiência do Judiciário pelo excessivo número de demandas ${ }^{15}$ - e por via transversa, o acesso à justiça. Desse apertado figurino, têm-se por conseqüência inicial, o descarte do principal mérito apontado para o sistema de stare decisis, a saber, a possibilidade genericamente oferecida de construção coletiva e continuada da compreensão dos institutos jurídicos.

Clara a má compreensão, pelos proponentes de nossa solução,

\footnotetext{
14 Inevitável consignar a combinação de cláusulas vagas: insegurança, que compreenderá todo o espectro de situações que se ponham além da zona de certeza positiva de segurança, vez que tanto há insegurança na zona de certeza negativa, como em toda a zona cinzenta de incerteza quanto a essa qualidade; e ainda grave, medida de intensidade que como tal, se reveste igualmente de palpável indeterminação, eis que sua caracterização depende do ponto mínimo que se adote por paradigma para essa aferição da gravidade.
} 
do instituto paradigma: o traço da vinculatividade - do funcionar como o critério hierarquicamente determinante da solução a ser conferida por instâncias inferiores do Judiciário — não se constitui, isoladamente, a essência do sistema. E isso se afirma, porque constitui igualmente elemento integrante do sistema de precedentes vinculantes — já se disse acima — as possibilidades do distinguishing e do overruling, que constituem justamente os mecanismos próprios a promover, por razões distintas, o apartamento do caso paradigma - logo, não é aplicabilidade coercitiva às instâncias inferiores que confere fisionomia ao sistema de precedentes vinculantes. Ao contrário, o caráter de obrigatória adesão se põe, no sistema inglês e norteamericano, como conseqüência, como coroamento do reconhecimento da formação de uma cadeia de consolidação da compreensão do Direito, ${ }^{16}$ que se iniciou — na verdade - junto ao juiz da causa, de primeiro grau, e que se enriquece com a contribuição dos demais agentes judicantes.

Vinculatividade, como instrumento vertical, de oferta de solução à divergência (portanto, de mediação de um conflito de entendimentos caracterizado nas instâncias inferiores), caminha lado a lado com a radicalização de um modelo hierárquico de Justiça, aumentando o fosso que separa o juiz da causa, da comunidade, dos detentores últimos do poder, que passam a deter a prerrogativa de vincular aos demais. Privilegia-se a hierarquia, em detrimento da agregação do conhecimento, elemento principal de legitimação da solução norte-americana e inglesa.

Adotadas, na definição dos pressupostos de cabimento da súmula vinculante, cláusulas vagas, têm-se por conseqüência a reserva de uma ponderável margem de discricionariedade em favor (exclusivamente) do STF - que, navegando na extensa zona de indeterminação quanto ao que possa ser grave insegurança jurídica e relevante multiplicação de processos, terá em suas mãos a última definição quanto a oportunidade para a edição do precedente vinculante; definição essa que não se sujeita (ao menos do ponto de vista prático) a qualquer outra apreciação crítica.

Descaracteriza-se ainda - com a outorga da competência, com exclusividade, em favor de uma única instância jurisdicional, tendo por base uma moldura de cabimento construída a partir de cláusulas vagas — a

\footnotetext{
15 Uma vez mais se pode apontar a baixa densidade da norma constitucional editada, na medida em que não se tem por claro qual seja o segmento do Judiciário (se primeiro grau, se Tribunais) — se é que é de se fracionar essa análise - cujo risco de multiplicação excessiva de causas deva ou possa desafiar súmula vinculante.

16 É de Cardozo (2004, p. 110-111) a imagem de que o sistema de precedentes permita "...assentar a própria fiada de tijolos sobre o alicerce sólido das fiadas assentadas pelos que vieram antes...".
} 
idéia de compromisso, permanente e transversal, de todo o Poder Judiciário, com a construção da compreensão das leis e do Direito posto, na medida em que cada juiz, não pode identificar o seu papel nessa tarefa de instituição de um precedente vinculante, que se formará (ou não), por decisão exclusiva do STF, segundo critérios que são de baixa sindicabilidade. Assim, enquanto no sistema norte-americano, todo juiz sabe que em toda atuação sua, constrói (ou contribui para desconstruir) precedentes vinculantes, esse mesmo sentimento de pertencimento à cadeia decisória, no sistema brasileiro, ou não existirá, ou terá por base elementos muito tênues.

Completa o quadro de perplexidades em relação ao traço "pacificador" ou "mediador" da súmula vinculante como instituída, a circunstância de também se incluir entre seus pressupostos de edição, cuidar-se de momento que se ponha “...após reiteradas decisões sobre a matéria constitucional...". ${ }^{17}$ E isso se diz porque também aqui se afasta a opção brasileira dos modelos clássicos em que supostamente busca inspiração, eis que a reiteração não se constitui condição para a caracterização de uma decisão como precedente vinculante nos sistemas norte-americano e inglês.

Importa ainda perceber que a alternativa de reduzir a possibilidade de conferir o signo da adesão obrigatória às hipóteses de controvérsia (e controvérsia qualificada, como já se disse), reservando-se ainda a competência privativamente ao Supremo Tribunal Federal constitui opção formal pela valorização prioritária da estrutura hierarquizada de organização da autoridade e da Justiça (DAMASKA 1986, p. 20-23), sem o correspondente benefício de construção de conhecimento agregado. Mais ainda, o modelo teórico fundado na hierarquia não encontra no Judiciário brasileiro, adesão a seus princípios, valendo por todos, aquele segundo o qual haja no modelo hierárquico, um desejo por uniformidade que conduza à afirmativa de que, idealmente, devam todos "... march to the beat of single drum..." (DAMASKA, 1986, p. 20). ${ }^{18}$ A função de mediação de conflitos, com decisões de adesão obrigatória, conferida ao órgão de cúpula da estrutura do Judiciário, consolida, portanto uma opção pela estruturação vertical da

\footnotetext{
17 O texto transcrito sugere outra perplexidade, na medida em que associado esse pressuposto (reiteradas decisões sobre a matéria constitucional) com aqueles contidos no art. 103-A, §1 ${ }^{\circ}$ (controvérsia entre órgãos e relevante multiplicação de processos) o resultado aparentemente, é no sentido de que a súmula vinculante só se pode verificar em matéria constitucional, o que significa desqualificar a controvérsia geradora de grave insegurança jurídica que envolva matéria infra-constitucional. No particular, todavia, sempre se poderá sustentar que o tema seja de opção política - e a crítica a essa, eficaz, a rigor, encontraria melhor lugar ao longo da discussão da iniciativa reformadora.
} 
autoridade judiciária, cumprindo subordinar a própria interpretação desse novo instituto a essa premissa teórica.

Uma alternativa de "salvação", ainda que parcial, do necessário envolvimento do Judiciário em maior abrangência, para com a fixação de um precedente de adesão obrigatória, e mesmo de abrandamento dessa radicalização em favor da hierarquia, será a exegese que se venha a conferir à referência contida no art. 103-A, caput da Carta de Outubro, de que a edição da súmula vinculante possa ser suscitada por provocação. Afinal, tendo em conta o princípio da unidade da Constituição, e considerando a regra contida no art. 103-A, §2 ${ }^{\circ}$ da CF, é sustentável a interpretação no sentido de que a "provocação" contida no caput, é distinta daquela proveniente dos órgãos estranhos ao Judiciário, restando, a contrario sensu, como terreno de incidência desta, as hipóteses de iniciativa pela própria Magistratura. Uma leitura desse teor, que permita - ainda que sujeita à ulterior definição de hipóteses de cabimento por lei, eis que o texto constitucional àquela complementação pelo Legislador alude - a provocação a partir do Judiciário, convida as Cortes a participar ativamente do processo de formação de um precedente vinculante, ${ }^{19}$ diminuindo a inclinação fortemente hierárquica denunciada pelo texto, aumentando o traço democrático de um instrumento dessa magnitude e importância. ${ }^{20}$

Observe-se que essa experiência — da provocação pelos níveis hierárquicos inferiores, da pronúncia por estrutura superior, detentora de competência para a apreciação da matéria constitucional — já existe como experiência no campo dos sistemas de controle concentrado de constitucionalidade, e pode portanto proporcionar alguma inspiração para um modelo que se venha a construir no campo da edição de súmula vinculante.

Completa o quadro de perplexidades em relação ao traço "pacificador" ou "mediador" da súmula vinculante como instituída, a circunstância de também se incluir entre seus pressupostos de edição, cuidar-se de momento

\footnotetext{
${ }^{18}$ Embora se possa afirmar que a disparidade de decisões envolvendo a uma mesma hipótese gere um sentimento de repúdio no âmbito do próprio Judiciário, que reverencia o valor de segurança jurídica como um imperativo a se buscar, nem por isso se pode dizer que desejem seus integrantes marcharem todos ao som do mesmo tambor. E se isso já não se põe no plano do genérico, com maior razão, as estruturas da base hierárquica do Judiciário resistem a essa verticalização das decisões, que a eles se apresenta como uma captio diminutio.

${ }^{19} \mathrm{Em}$ verdade, quem melhor poderá depor acerca dos riscos de relevante multiplicação de processos — por exemplo - que as Cortes que, primariamente, com eles se defrontam?

20 Importante, de outro lado, evidenciar que a sistematização, por Cortes de hierarquia inferior, dos termos do conflito a merecer apreciação por parte do órgão de cúpula, também é apresentado por Damaska (1986, p. 20) como característica da estrutura hierarquizada de exercício de autoridade. No contexto, todavia, a admissibilidade da provocação por magistrados ou tribunais de outro patamar hierárquico, contribuiria para um nível de abertura do sistema — e não de maximização do traço vertical.
} 
que se ponha “...após reiteradas decisões sobre a matéria constitucional...”. Afinal, a literalidade do texto pode conduzir à compreensão de que não caiba a edição de súmula vinculante, em hipóteses em que a grave insegurança jurídica e a possibilidade de relevante multiplicação de processos sobre questão idêntica, envolva a aplicação de normas infra-constitucionais - o que nem por isso, desqualificará a controvérsia. Assim, os valores pretendidos tutelar com a possibilidade da instituição de súmula vinculante não são particulares às normas constitucionais; logo, a solução oferecida pode se mostrar acanhada para as finalidades que pretenderia alcançar. ${ }^{21}$

É certo que sempre poderá o Supremo Tribunal Federal operar a inclusão de determinado tema no espectro de cabimento da edição de súmula vinculante, qualificando o debate sobre a lei infra-constitucional como tema envolvendo quaestio de inconstitucionalidade reflexa. Essa, todavia, é rota que passa por terreno pantanoso, seja porque o tema da competência para a análise pelo STF da inconstitucionalidade reflexa sempre encontrou resistência no âmbito da própria Corte, seja porque - justamente pela escassa prática de tal análise - não se tem ainda adequadamente construídos os critérios que permitam a identificação precisa desse fenômeno. O caminho, portanto, do alargamento da compreensão dos temas passíveis de edição de súmula vinculante pode conduzir à traição constitucional, conferindo-se ao STF maior espectro de poder que o exercício de poder constituinte reformador lhe pretendeu conferir.

\section{Segunda crítica à versão brasileira de vinculatividade de decisões judiciais: a resposta constitucional à contrariedade ou má aplicação da súmula}

Completa-se o sistema de precedentes vinculantes instituído pela Emenda Constitucional 45/04, com a regra expressa no $\S 3^{\circ}$ do art. 103-A da Carta de Outubro, que prevê a possibilidade de oferta de reclamação ao Supremo Tribunal Federal, “...do ato administrativo ou decisão judicial que contrariar a súmula aplicável ou que indevidamente a aplicar...”. Em se cuidando a reclamação, por sua vez, de instituto também com assento constitucional, cumpre ter-se em conta os termos do art. 102, I, "l" da Norma Fundamental, que consagra seu cabimento, como instrumento de competência originária, “...para a preservação de sua [do STF] compe-

\footnotetext{
${ }^{21}$ É também de Moreira Lima (2001, p. 114) a afirmação de que a grande inspiração do modelo de súmula vinculante, então ainda em proposta, tinha por principal objetivo "...diminuir o número de ações e recursos que tem de ser decidido pelos tribunais..."
} 
tência e garantia de suas decisões...”.

Da conjugação dos dois dispositivos constitucionais, é possível extrair por conclusão que o valor tutelado pela reclamação manejada por ocasião da aplicação da súmula vinculante, é a garantia das decisões do STF — na medida em que aplicação em si da súmula é atividade que, por princípio, se dará fora dos limites do próprio Tribunal Supremo. ${ }^{22}$

E qual a natureza jurídica dessa atividade, desenvolvida agora, pelo órgão de cúpula do Poder Judiciário? Não parece haver dúvida, seja jurisdicional - diferentemente, como se sabe, da edição de súmulas (não vinculantes), que se deu, historicamente, a título de exercício de função administrativa.

Vários são os fundamentos que se pode apontar para o caráter jurisdicional da decisão que aprova súmula vinculante. Primeiro, porque nessa providência, associam-se, conforme preceituado por Canotilho (2001, p. 645), os critérios materiais e substantivos, àqueles de atribuição subjetivo-orgânica: a decisão se dá por órgão dotado de jurisdição, e tem por pressuposto (dentro outros), controvérsia atual entre órgãos do judiciário. A moldura de cabimento da súmula vinculante pressupõe, portanto, prestação não uniforme, de jurisdição; e é confiada a órgão jurisdicional - logo, de jurisdição, se cuida.

Dir-se-á, em contradita: mas qual a lide, qual o conflito de interesses envolvidos na apreciação pelo STF, de uma hipótese que envolva a possível edição de súmula vinculante? Partindo da afirmativa constitucional de que essa atividade pressupõe grave insegurança jurídica - avaliada quando se cogita de vincular decisões por aplicação do sistema instituído pelo art. 103-A da CF — têm-se já necessariamente presente um interesse difuso, apto a determinar, em busca de sua tutela, exercício de função jurisdicional. É certo que esse interesse difuso, de afastamento da incerteza jurídica (situação incompatível com o modelo de Estado Democrático de Direito), pode ser trazido à consideração sem a rígida observância do princípio da inércia, regedor da prestação tradicional de jurisdição: o STF pode, de ofício, optar por esse caminho. Disso, todavia, não se pode extrair a compreensão de que se tenha por desnaturada a função jurisdicional.

\footnotetext{
22 Essa afirmação se faz a partir dos termos do art. 103-A, caput, que prevê a geração de efeito vinculante justamente em relação a outros órgãos do Poder Judiciário e à administração pública, o que está a demonstrar ser esse o locus de sua aplicação, sem que disso resulte qualquer arranhão à competência do STF. Esse, ao revés, normalmente, só se verá na contingência de aplicar a súmula vinculante quando chamado, ou a apreciar reclamação, ou a examinar provocação à sua revisão ou cancelamento (art. 103A, caput $\left.\mathrm{c} / \mathrm{c} \S 2^{\circ} \mathrm{da} \mathrm{CF}\right)$.
} 
Afinal, como já se viu, a moldura constitucional que abre essa possibilidade de atuação ao STF pressupõe “...controvérsia atual entre órgãos judiciários...”; logo, prestação anterior de jurisdição, cujo conjunto entre em rota de colisão, e esteja a exigir solução mediadora.

Se essa afirmação - de que a decisão pela edição de súmula vinculante tenha natureza jurisdicional — se faz nas hipóteses de atuação de ofício do STF, com maior razão se fará nos casos de provocação, seja fundada no art. 103-a, caput da CF; seja nas hipóteses de seu $\S 2^{\circ}$; eis que ainda que submetida a quaestio objetivamente (sem associação imediata a um conflito de interesses inter-subjetivo) nem por isso se terá por descaracterizada a jurisdição, como se tem por assentado, por exemplo, no controle abstrato de constitucionalidade.

É essa compreensão - de que se cuide de pronúncia revestida de natureza jurisdicional - que melhor emprestará sentido, como já se disse, à previsão de cabimento de reclamação em defesa da adequada observância dos termos da decisão do STF, que como remédio extremo que é, de assento constitucional, não poderia se destinar à garantia de decisões de caráter meramente administrativo (como o é a aprovação de enunciado não vinculante).

Pois bem. Mas retomada a questão proposta a esse subitem, têmse que o art. 103-A, §3 da CF prevê o cabimento da reclamação “...do ato administrativo ou decisão judicial que contrariar a súmula aplicável ou que indevidamente a aplicar...”. Uma leitura literal do dispositivo, adicionada à conclusão de que se cuide a edição de súmula vinculante de decisão jurisdicional, levará à conclusão de que praticamente, toda a aplicação desse enunciado de adesão obrigatória, abrirá cabimento à reclamação. Isso porque, em havendo duas partes em posições antagônicas, toda e qualquer aplicação do preceituado vinculativamente pelo STF, poderá ser entendido pela parte perdedora como contrariedade ou má aplicação da súmula. Põe-se então a indagação: a oferta de reclamação, prevista no art. 103-A, $\S 3^{\circ}$ da CF, se porá como possibilidade ab initio, tendo em conta justamente o imperativo de tutela de sua força vinculante; ou ao contrário, existente meio de impugnação ainda disponível ao interessado, deverá ele de tal recurso se valer?

A questão, a rigor, não é inédita quando se cogita de reclamação. É de Dantas (2000, p. 484-485) a notícia de que o tema do caráter supletivo do instituto já ocupou a crônica da jurisprudência dos Tribunais Supe-

A \& C R. de Dir. Administrativo e Constitucional, Belo Horizonte, ano 5, n. 21, p. 69-88, jul./set. 2005 
riores, não sendo possível apontar qual seja a tendência dominante de resposta. O perfil, todavia, do sistema instituído pela Emenda Constitucional 45/04 ao instituir a súmula vinculante, introduz características a essa particular hipótese de cabimento de reclamação, que determinam seu caráter subsidiário, como se passa a demonstrar.

Primeiro elemento que se traz — orientador de uma interpretação que reverencie ao princípio da unidade da Constituição - é o finalístico, e em duas das suas projeções consagradas no novo instituto. Cuida-se de súmula vinculante, e como tal, produz efeitos subordinantes "...em relação aos demais órgãos do Poder Judiciário e à administração pública...”. Disso portanto decorre que o compromisso de zelo pela sua adequada aplicação se estende por toda a estrutura do Poder Judiciário, que é co-responsável pelo enforcement da orientação fixada pelo Supremo Tribunal Federal. Admitir, portanto, a reclamação, como primeira providência, em hipóteses de vislumbrada má aplicação dessa mesma súmula, importa em verdadeiro voto de desqualificação do restante do Judiciário, que já se supõe, na análise de eventual meio de impugnação interposto, não restauraria a autoridade da decisão sumulada pelo STF. Contraria portanto o espírito do sistema contido no art. 103-A da CF, a compreensão de que a reclamação prevista em seu $\S 3^{\circ}$ possa ser oferecida, em caráter autônomo, como primeiro meio de manifestação do inconformismo da parte com relação à aplicação da súmula.

É de se observar ainda que, mesmo em se cuidando de precedente de adesão obrigatória, é de se reconhecer ao juiz que o aplica ao caso concreto, a necessidade de aplicação do mesmo iter percorrido para a extração do critério jurídico de solução a partir do texto legislativo. ${ }^{23}$ Afinal, o modelo nacional de precedentes vinculantes se referencia, não a um caso com a íntegra de seus elementos determinantes, mas sim a um enunciado abstrato, que em tudo e por tudo se assemelha à função legislativa positiva — aquela mesma que o Supremo Tribunal Federal, por várias vezes, negou possuir. ${ }^{24} \mathrm{E}$ se ao juiz se reconhece um necessário caminha de interpretação a percorrer, a conseqüência será admitir-se seu diálogo com o precedente vinculante, como leciona Calmon de Passos (2002, p. 15):

\footnotetext{
${ }^{23}$ É de Calmon de Passos (2002, p. 14), ainda quando sequer se tinha aprovada a Emenda 45/04, a afirmação de que o modelo de precedente vinculante então em gestão determinava a edição de norma assemelhada àquela de competência do legislador: Guardando coerência com a posição defendida, devese aproximar a súmula, ou jurisprudência com força vinculante, da norma de caráter geral de natureza interpretativa editada pelo legislador. Nem pode valer mais, nem deve valer menos.
} 
Assim sendo, inaceitável se negue a liberdade reconhecida ao juiz para interpretar a norma de caráter geral que lhe cumpre aplicar ao caso concreto, quando se cuide de interpretação de súmula vinculante. Donde ser admissível sua inaplicabilidade ao caso concreto, desde que justificada a posição do magistrado, tal como ocorre quando se cuida da hermenêutica de um dispositivo legal. Tudo será problema de clareza e de pertinência da fundamentação oferecida. Essa paridade entre a lei (norma geral) e a súmula vinculante (norma interpretativa de caráter geral) é indispensável e se me afigura, como dito antes, uma decorrência do sistema.

Será próprio, portanto, da aplicação da súmula vinculante, dado o caráter genérico de que se revestirá seu enunciado, abrir espaço à interpretação, e a esse exercício não se pode pretender associar diretamente, a caracterização de lesão à autoridade da decisão do Supremo Tribunal Federal, que desafie de já, sem o percurso da escala recursal ordinária, à reclamação. Nem mesmo os extremos do positivismo - com sua pretensão de suficiência do enunciado normativo - autorizaram a remessa direta à Corte Suprema, via reclamação, de temas examinados pelo Judiciário em suas instâncias inferiores, e que não se tivessem conduzido à solução desejada pela parte.

Também aponta essa mesma conclusão, o caráter profiláctico de "relevante multiplicação de processos sobre questão idêntica", ao qual se associa também a edição de súmula vinculante. Também seria desarrazoado que um instrumento voltado para a prevenção da multiplicação de feitos tivesse por conseqüência, autorizar justamente a apresentação de incontáveis reclamações, dirigidas — como são — ao órgão de cúpula da estrutura do Poder Judiciário. É oportuno ainda registrar que essa concepção, a rigor, nem mesmo se harmoniza com os alicerces de um modelo de organização de justiça fundado na hierarquia, único no qual se pode admitir uma ferramenta com os contornos que se apresentam à súmula vinculante. Uma vez mais, é Damaska (1986, p. 20) quem adverte que nas estruturas hierarquizadas, a irreversibilidade das decisões de níveis mais altos demanda, como elemento de prevenção de erros, um menor número de demandas alcançando a esse mesmo patamar, e um espectro

\footnotetext{
24 RE 309381 AgR / DF - DISTRITO FEDERAL, Relator(a): Min. ELLEN GRACIE, Julgamento: 15/06/2004, Órgão Julgador: Segunda Turma, Publicação: DJ DATA-06-08-2004 PP-00053 EMENT VOL-02158-04 PP-00784; RE 322348 AgR / SC - SANTA CATARINA, Relator(a): Min. CELSO DE MELLO, Julgamento: 12/ 11/2002, Órgão Julgador: Segunda Turma, Publicação: DJ DATA-06-12-2002 PP-00074 EMENT VOL02094-03 PP-00558, e tantos outros.
} 
mais limitado de análise, "triagem" essa que é empreendida pelos órgãos inferiores. Contraria, portanto, toda a lógica do sistema hierárquico, um alargamento das hipóteses de cabimento de reclamação.

É certo que os dois elementos que até agora se utilizou como fundamento de argumentação se constituem pressupostos à edição da súmula vinculante - e não da providência de conseqüência à sua má utilização pela Corte. Nem por isso, todavia, se pode desconsiderar a finalidade que a rege quando se cuida justamente de sua suposta inobservância.

A conclusão que se oferece, portanto, é no sentido de que uma interpretação que tenha em conta, não a literalidade do dispositivo, mas o sistema que se institui, conduzirá necessariamente ao caráter subsidiário da reclamação prevista no art. 103-A $\S 3^{\circ}$ da CF. Dir-se-á: mas na hipótese da efetiva má aplicação da súmula, o percurso prévio de toda a via recursal pode gerar ao atingido danos irreversíveis ou de difícil reparação, e mais ainda, pode erodir a autoridade da súmula vinculante... Ora, essa conclusão só será possível se partirmos igualmente do pressuposto de que todo o Poder Judiciário - a exemplo da autoridade reclamada - compactuem desse desprestígio a precedente de adesão obrigatória, que não encontraria portanto, pelo manejo dos meios legais de impugnação, a devida recondução a seus termos. Mas se assim for, estaríamos conduzindo todo o raciocínio a partir do patológico, e esse exercício, jamais será apto a gerar respostas sistêmicas adequadas, eis que o patológico, até por isso, é também o imprevisível.

\section{Terceira crítica à versão brasileira de vinculatividade de decisões judiciais: a inconsistência sistêmica}

Já o título do presente ensaio anuncia a fragilidade sistêmica da súmula vinculante, como instituídas no direito pátrio. A par das considerações desenvolvidas em maior detalhe, é possível ainda apontar a contradição em importar-se o convívio híbrido entre a provocação a partir do caso, e aquela que se dá objetivamente (art. 103-A §2 da CF), situação que, no campo do controle de constitucionalidade, gera inúmeros inconvenientes. O total silêncio no que toca à zona de fronteira entre o terreno próprio à súmula vinculante, e aquele reservado ao controle constitucionalidade ${ }^{25}$ também é importante matéria não enfrentada - e com isso, fragiliza-se o sistema.

A impressão que resta, é de que o texto tem a configuração que 
tem, porque essa foi a solução de compromisso a que se pôde chegar, para institucionalizar uma idéia ${ }^{26}$ que, embora antiga, jamais se positivara. E as soluções de compromisso, embora possa eventualmente ser satisfatórias politicamente, poucas vezes o são tecnicamente, até porque no mais das vezes, não contam com o tempo como aliado ao amadurecimento da proposta.

É bem verdade que o Projeto de Emenda à Constituição que veio a se converter na Emenda Constitucional 45/04 (PEC 96) foi publicado no Diário do Congresso Nacional, na sua primeira forma, em $1^{\circ}$ de maio de 1992. Também não é menos verdade que essa mais de uma década despendida no Parlamento modificou-lhe sobremaneira os contornos; o tema da vinculatividade das decisões, foi introduzido formalmente na discussão através da PEC 500-A, de 1997, do Senado Federal, ${ }^{27}$ e coexistiu - como de resto ainda coexiste - com a súmula impeditiva de recursos, ambas apontadas como possíveis soluções àquele tema que na verdade, sensibilizava mesmo ao constituinte reformador, que era tão-somente a sobrecarga e o risco à incapacidade de resposta pelo Judiciário.

Não se tinha, portanto, à época da articulação da discussão — como de resto hoje ainda não se tem - uma visão clara de como se possa associar, vinculatividade com justiça do caso concreto; adesão obrigatória com máxima efetividade desse mesmo caráter. Não por outra razão, já advertia Calmon de Passos (2002, p. 16) quanto aos inconvenientes da proposta, ${ }^{28}$ não quanto ao mérito da idéia, mas quanto à sede que se lhe apontava, que a título de lhe conferir maior autoridade, o que resultava mesmo era uma rigidez indesejável - em verdade, uma antítese às próprias idéias que permeiam a elaboração doutrinária alienígena de sistema de precedentes.

O resultado de uma falta de maturidade teórica, associada aos percalços de tramitação da Emenda, é a criação de um instituto que carece de coerência interna, e que se propõe a resultados que — aparentemente

\footnotetext{
${ }^{25}$ A combinação de controle difuso de constitucionalidade $\mathrm{cm}$ súmula vinculante pode, no extremo, conduzir a resultados que o sistema de controle abstrato de constitucionalidade não permite, eis que se pode conferir signo de vinculatividade a decisões envolvendo constitucionalidade, por exemplo, de lei municipal, ou de lei revogada - matérias que hoje, só admitem decisão com efeitos erga omnes se passíveis de veiculação no estreito figurino ad ADPF.

${ }^{26}$ Essa, aliás, é a afirmação já da Dep. Zulaiê Cobra, quando da apresentação do substitutivo, que veio a conferir o ritmo e rumo à votação, ao aludir à busca de um " ,.,consenso, [que] só será alcançado com o encontro de vontades visando um fim comum...".

${ }^{27}$ Essa é a narrativa da Comissão Especial destinada a proferir parecer à Proposta de Emenda à Constituição $n^{\circ}$ 96-A, de 1992, que "INTRODUZ MODIFICAÇÕES NA ESTRUTURA DO PODER JUDICIÁRIO" e apensadas; publicado no Diário do Congresso Nacional em 14 de dezembro de 1999, p. 832 e seguintes, Relatora, a Dep. Zulaiê Cobra.
} 
— não se revela capaz de alcançar, sem grave subversão de outros preceitos de sede também constitucional, atinentes à competência dos tribunais, quiçá, ao acesso à justiça. O que se pode prever é uma construção de sentido, a ser desenvolvida provavelmente pelo próprio Supremo Tribunal Federal, que caminhe firmemente na linha da cautela.

E esse, talvez, seja efetivamente o caminho que recomenda a prudência. A construção doutrinária restritiva do cabimento das hipóteses de edição de súmula vinculante permitirá a absorção gradual da cultura do precedente, e do modo de argumentação - e sobretudo, de fundamentação das decisões - que lhe é próprio. De outro lado, ampla há de ser a compreensão no que toca aos instrumentos destinados à provocação da revisão ou cancelamento da súmula de observância obrigatória. Afinal, a falta de experiência com a solução demanda espírito crítico em relação a ela, e nada favorecerá mais essa crítica, que a ampla admissibilidade da provocação pelo próprio Judiciário, e ainda aquela por intermédio do instrumento previsto no art. 103-A $\S 2^{\circ}$ da CF.

Muito se debateu, no que toca ao tema da súmula vinculante, sobre sua legitimidade democrática, pelo que ela (pode) significar de rearranjo da distribuição de poder, dentro e fora do Judiciário. Introduzida, todavia, a mudança constitucional, ainda restará — no suposto de que legitimidade não estivesse na raiz da proposta - construir seus contornos sob esse signo. E essa é uma tarefa que caberá, não à Corte isoladamente, mas ao conjunto dos operadores do Direito.

\section{Bibliografia}

BLACHÈR, Philippe. Controle de Constitutionalité et Volonté Générale. Paris, France: Presses Universitaires de France, 2001.

CALMON DE PASSOS, José Joaquim. Súmula Vinculante. Revista Diálogo Jurídico, Salvador, n. 10, jan. 2002. Disponível em: <http://www.direitopublico.com.br>. Acesso em: 5 jul. 2005.

CARDOZO, Benjamin N. A Natureza do Processo Judicial: Palestras Proferidas na Universidade de Yale. Trad. Silvana Vieira. São Paulo: Martins Fontes, 2004. Traduzido de The Nature of the Judicial Process.

CASTANHEIRA NEVES, A. O Actual Problema Metodológico da Interpretação Jurídica. Coimbra: Coimbra Ed., 2003.

COLE, Charles D. Precedente Judicial: a Experiência Americana. Revista de Processo Nacional, como redigida, só causará mais rigidez, tumulto e insegurança, em matéria que melhor seria tratada em termos de legislação ordinária, precedida de boa sedimentação doutrinária, salvo se a racionalidade, senso do razoável e fidelidade ao dever constitucional, associados à função de julgar, forem bastantes para nos dar o equilíbrio que só a consciência da responsabilidade dos papéis sociais que nos cumpre desempenhar proporciona, jamais os enunciados jurídicos, um modo de dizer, impotente para fazer com que as coisas sejam como ele diz que devem ser, quando se ausenta dos responsáveis a consciência do cumprimento do dever, como já advertido, há muitos anos, por um grande brasileiro. 
(REPRO), ano 23, n. 92, out.-dez. 1998, p. 71-86.

DAMASKA, Mirjan R. The Faces of Justice and State Authority: a Comparative Approach to the Legal Process. New Haven and London: Yale University Press, 1986.

DANTAS, Marcelo Navarro Ribeiro. Reclamação Constitucional no Direito Brasileiro. Porto Alegre: Sergio Antonio Fabris, 2000.

DWORKIN, Ronald. O Império do Direito. Trad. Jefferson Luiz Camargo. São Paulo: Martins Fontes, 1999. Traduzido de Law's Empire.

GRECO, Leonardo. Novas Súmulas do STF e Alguns Reflexos sobre o Mandado de Segurança. Revista Dialética de Direito Processual (RDDP), n. 10, jan. 2004, p.44-54.

MOREIRA, José Carlos Barbosa. O Futuro da Justiça: Alguns Mitos. Revista de Direito da Procuradoria Geral do Estado do Rio de Janeiro, n. 53, 2000, p. 27-36.

LEAL, Rosemiro Pereira. Teoria Processual da Decisão Jurídica: Atos de Decisão e Legitimidade Decisória, Hermenêutica Decisional na Teoria Discursiva e Legitimidade Decisória e devido processo constitucional. São Paulo: Landy, 2002.

MacCOMRICK, D. Neil; SUMMERS, Robert S. Interpreting Precedents: a Comparative Study. Great Yarmouth, Great Britain: Dartmouth, 1997.

MOREIRA LIMA, Augusto César. Precedentes no Direito. São Paulo: LTr, 2001.

ROSS, Alf. Direito e Justiça. Trad. Edson Bini, 1ª reimp. Bauru, São Paulo: EDIPRO, 2003. Traduzido de On Law and Justice.

STRECK, Lenio Luiz. Jurisdição Constitucional e Hermenêutica: uma Nova Crítica do Direito. Porto Alegre: Liv. do Advogado, 2002.

TARUFFO, Michele. Precedente ed Esempio nella Decisione Giudiziaria. Rivista Trimestrale di Diritto e Procedura Civile, Milano, ano XLVIII, 1994a, p. 19-36.

TARUFFO, Michele. Dimensioni del Precedente Giudiziario. Rivista Trimestrale di Diritto e Procedura Civile, Milano, ano XLVIII, 1994b, p. 411-430.

Informação bibliográfica deste texto, conforme a NBR 6023:2002 da Associação Brasileira de Normas Técnicas (ABNT):

VALLE, Vanice Lírio do. Impasses sistêmicos da versão brasileira de precedentes vinculantes. AESC Revista de Direito Administrativo e Constitucional, Belo Horizonte, ano 5, n. 21, p. 69-88, jul./set. 2005.
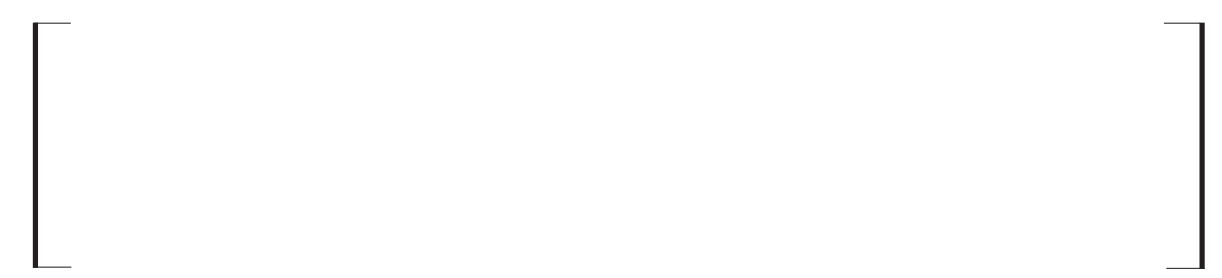

A \& C R. de Dir. Administrativo e Constitucional, Belo Horizonte, ano 5, n. 21, p. 69-88, jul./set. 2005 